\title{
RELICS OF MINING ACTIVITIES IN WEST BOHEMIA - MAPPING BY AIRBORNE LASER SCANNING
}

\author{
M. Faltýnová *, K. Pavelka
}

Department of Mapping and Cartography, Faculty of Civil Engineering, Czech Technical University in Prague (faltynova, karel.pavelka)@gmail.com

KEY WORDS: Medieval mines, ALS, Shaded relief, DTM, Archaeology, Jáchymov

\begin{abstract}
:
The part of the Czech Republic - West Bohemia is well known for mining activities, different types of raw materials have been extracted from mines near Jáchymov, Sokolov and other sites since medieval times till today. There are original maps of some sites, as well there is effort of some geologists to find and map relics of mining activities (such as digs visible in terrain) by land survey. The quality of these available maps is unfortunately questionable - due to its age or used methods. Our aim was to find resource useful for searching for these sites, than to use field survey to confirm our findings. We used available digital terrain model (DTM) based on airborne laser scanning (ALS) technology to map relics of mining activities in West Bohemia. The Czech Office for Surveying, Mapping and Cadastre started in 2008 project for terrain mapping using the ALS method. The aim of mapping was to get authentic and detailed DTM of the Czech Republic. About $2 / 3$ of area is currently covered by the DTM based on ALS, this year the mapping should be complete. The dataset is characterised by the density of $1-2$ points $/ \mathrm{m}^{2}$ and the standard deviation in altitude of model points is up to $30 \mathrm{~cm}$ (in forested areas). We had DTM in form of shaded surface for one third of the Czech Republic. The shaded surface enables to highlight terrain break lines, which is suitable for archaeological research. Terrain modifications caused by human activity are characterized by terrain break lines, local tops or pits, which do not fit to local geomorphology. Visual image interpretation of the dataset is in the process.
\end{abstract}

\section{INTRODUCTION}

For several years, our research group has been interested in using airborne laser scanning for searching for archaeological sites such as abandoned settlements (Faltýnová, Pavelka, 2011), documentation of already known sites (Faltýnová et al., 2013) and also using terrestrial laser scanning for mapping objects in area of cultural heritage protection (Pavelka et al., 2010). During visual prospection of available ALS dataset we found amount of remains of mining activities and we focused on potential of the dataset for documentation of historic mining activities.

History of mining activities in the area of the Czech Republic is described in detail in (Majer, 2004) and (Jirásek, 2010). West Bohemia is well known for mining activities and different types of raw materials have been extracted from mines near Jáchymov, Sokolov and other sites since medieval times till today. Especially in the vicinity of Jáchymov there were silverfields exploited since $16^{\text {th }}$ century (Majer, 2004). We have chosen this locality for the case study.

Airborne laser scanning technology is successfully used in nondestructive archaeology (Kuna et al., 2004) and find its application mainly in forested areas (Doneus et al., 2008). The technology has been used in the Czech Republic in case study at Jistebsko (Gojda et al. 2013). There is an extensive Neolithic quarry site, where there was extracted the material for stone axes. ALS technology enabled an identification of a previously unknown part of the Neolithic quarry site, which was overlooked before because of a dense vegetation cover.
Soon there will be available ALS dataset and detailed DTM based on this dataset for the entire area of the Czech Republic and the aim of this paper is to show its potential for documentation of old mining activities in forested areas on a case study in region Jáchymov. There are original maps of the sites, which were used as well.

\section{DATA}

\subsection{Airborne Laser Scanning Dataset}

In our project we used data acquired by the Czech Office for Surveying, Mapping and Cadastre (ČUZK). Since the spring of 2010 the entire area of the Czech Republic was mapped by ALS (full-waveform scanner RIEGL LMS 680 is currently being used) with an expected finishing date by the end of 2013. Investors of this project are the Czech Office for Surveying, Mapping and Cadastre, the Ministry of Defence and the Ministry of Agriculture of the Czech Republic. This dataset is being used to obtain a highly accurate digital terrain model for the purposes of administration, for example in the detection of flooded areas, orthorectification of areal images etc.

Parameters for scanning have been set to gain a point cloud with a density of about 1 point $/ \mathrm{m} 2$ and with a side overlap of adjacent strips of about $50 \%$. Typical product of this mapping is a DTM in form of a regular grid or a triangulated irregular network (TIN). Further details can be found in (Dušánek, 2011). We used original point clouds and the DTM displayed in form of shaded relief.

\footnotetext{
* Corresponding author.
} 


\subsection{Historical Mining Maps}

Ore deposits had been traditionally mapped and there are still original maps of some sites. The quality of these maps unfortunately corresponds to the period of origin - the accuracy of the maps is poor due to or used methods. Despite this fact the original maps can give us useful information and can be compared to modern datasets such as a DTM based on ALS (Bofinger, 2006). On the other side, most of these maps have incalculable historical value and are works of art but its information value is questionable (Fig. 1)

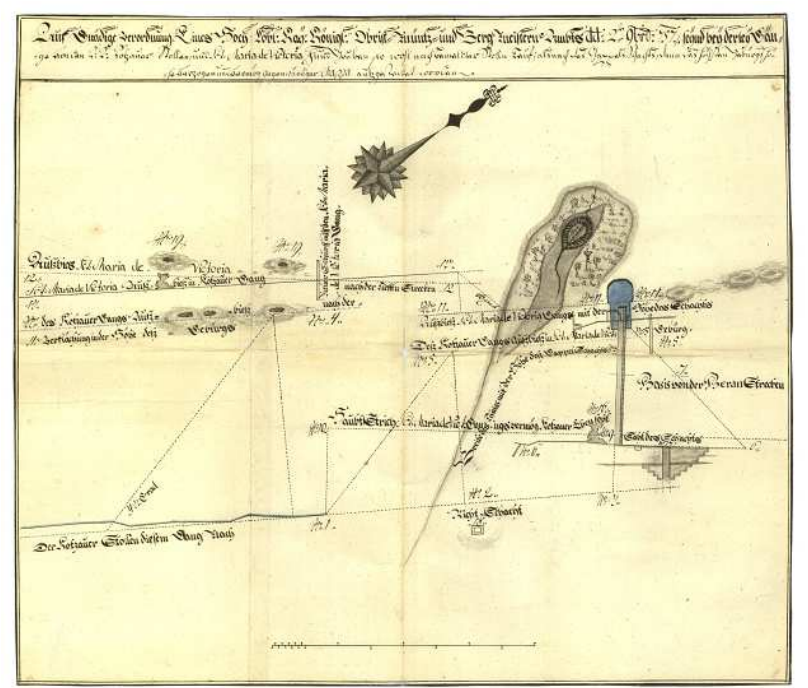

Figure 1. Mines in Jáchymov (1757) - from ČGS archive

The Czech Geological Survey (ČGS) on its websites provides historical maps or at least enables preview of the maps through web map service (WMS) or digital archive. Maps that have not yet been digitized are available for inspection in study room at the archive of the Czech Geological Survey.

\section{REMAINS OF MINING ACTIVITY IN DIGITAL TERRAIN MODEL}

\subsection{Site}

Jáchymov is one of the most frequently used ore district in Czech part of the Ore Mountains. Mining history of this region started in $16^{\text {th }}$ century by silver fever and over the centuries deposits of different ores were found in this region - besides silver, also bismuth, nickel, cobalt and uranium. We have chosen two sites - site in direct neighbourhood of the city Jáchymov (Fig. 2) and few kilometres further hill Mědník (Fig. 3).

\subsection{Digital Terrain Model}

Mining activity left significant scars on Earth surface - terrain modifications characterized by terrain break lines, local tops or pits, which do not fit to local geomorphology. This terrain forms can be found almost unchanged after centuries in forested areas, where heavy machines didn't damage it.

To create DTM from point clouds at first the filtration has to be done. Filtering means separation point clouds into terrain and off-terrain points. A variety of developed filtering methods (Sithole \& Vosselman, 2004) points to the importance of quality filtering algorithms for the determination of high quality digital terrain models. The automatic filtering method was used, but some parts of the model had to be refined by semi-automatic function (for both used TerraScan software).

From filtered points the DTM in form of TIN and shaded relief were created. Local pits and tops can be detected for example by creation of detailed and smoothed DTM. By later subtraction smoothed and detailed DTM the local differences become clearly visible. Another way is to use shaded relief, which simulates the cast shadow thrown upon an Earth's surface. The shadows most frequently follow the convention of top-left lighting. Chosen direction of lighting strongly affects what can be clearly seen in the relief. As a consequence terrain edges that follow the illumination direction are not visible in shaded relief.

\subsection{Results}

From shaded relief (Fig. 2) it is clear where are the mining pits surrounded by excavated material. Some of them lie in-line and show where the lodes go.

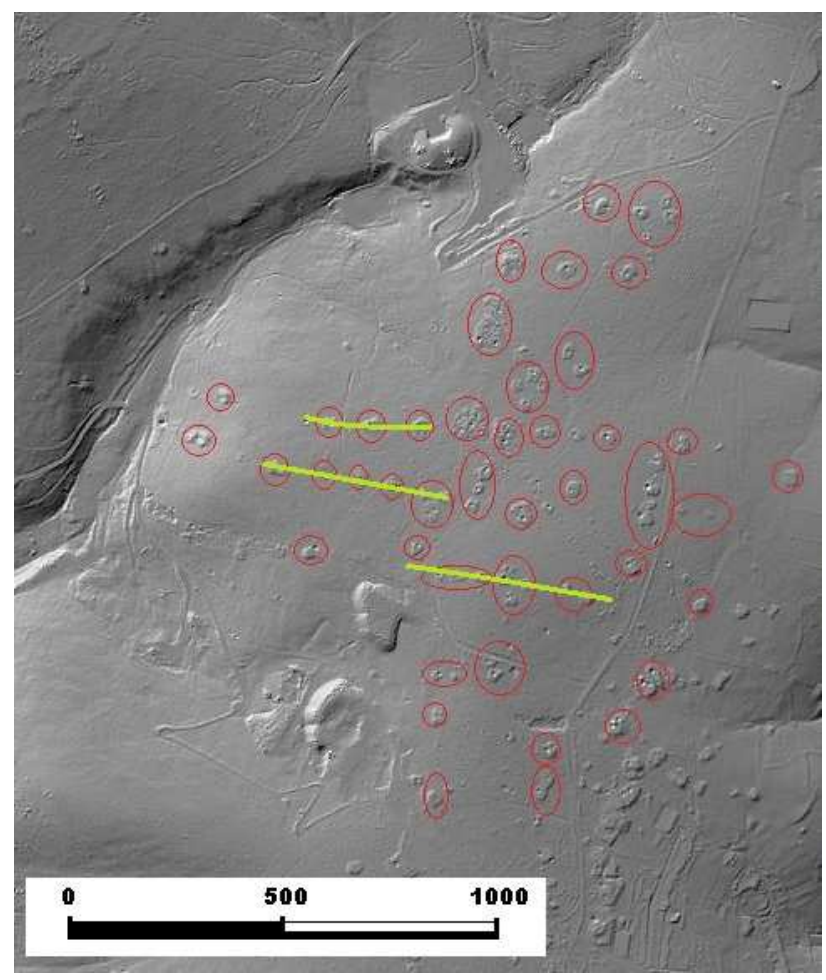

Figure 2. Shaded relief - Jáchymov

\section{COMPARING DATASETS}

Situation of the second site hill Mědník was described in mining map from 1788. The scale of map was 1:1370. Our aim was to compare the original mining map with shaded relief based on ALS. It was essential to find identical points in both dataset to transform original map. The original map doesn't include enough additional labels to identify any objects. So we started with presumption that the orientation and the scale of the map are approximately correct. Then we moved the map over shaded relief and tried to find position in which the drawn gangues masked pits in relief. After all we slightly revised the orientation and the scale. We used simple similarity transformation. The identical points are in red circle (Fig. 3). Affine transformation would be also possible because 
the shrinkage of paper map could be different in different direction.

Some of the objects drawn in original map are not visible in shaded relief. These objects may have wrong position in the map or they didn't caused obvious terrain change. As we mentioned before, the accuracy of the map is at least questionable, but we will make field survey to try find these objects.

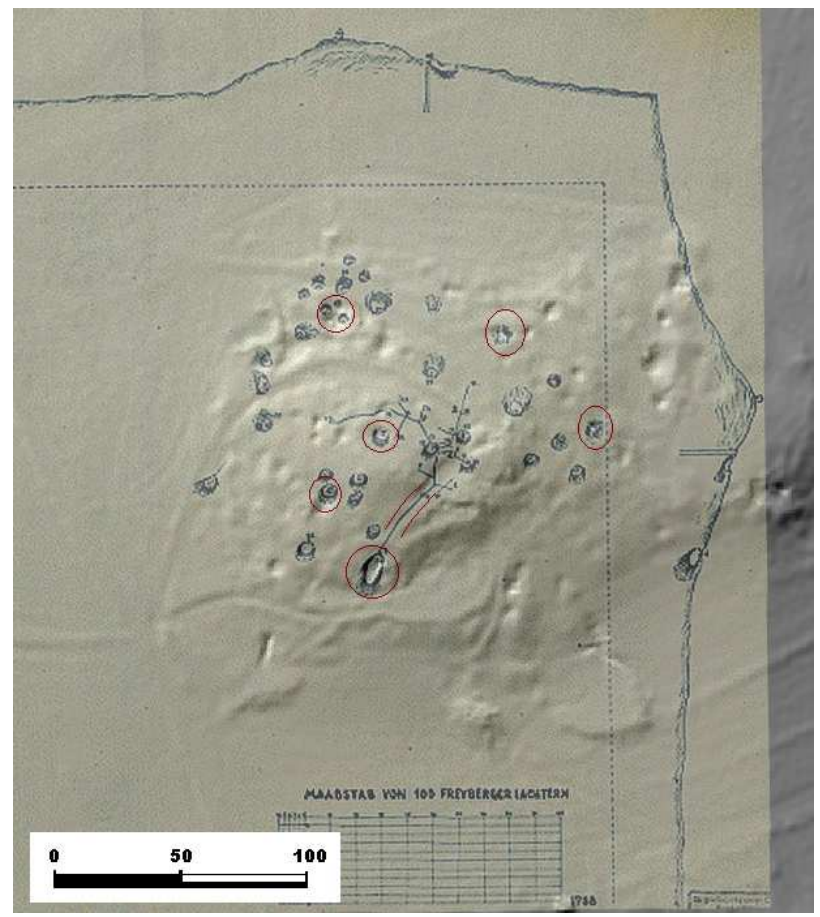

Figure 3. Mědník - DTM in form of shaded relief and mining map (1788) - from ČGS archive

\section{CONCLUSION}

In this project we have used the ALS dataset that will be soon available for the whole area of the Czech Republic. It has demonstrated its strengths for mapping manmade structures such as remains of mines covered by dense forests. We also compared this data with original mining map, which gave us new impulse for field survey. The ALS technology give us strong tool but the need for surface verification of individual discoveries also became apparent. With little knowledge about the local terrain, the objects could have been mistaken.

\section{REFERENCES}

Bofinger J. - Kurz, S. - Schmidt, S. 2006. Ancient maps modern data sets: different investigative techniques in the landscape of the Early Iron Age princely hill fort Heuneburg, Baden-Wurttemberg. In S. Campana, - M. Forte (eds): From Space to Place. 2nd International Conference on Remote Sensing in Archaeology. BAR International Series $1568,87-92$.

Doneus M. et al. 2008. Archaeological prospection of forested areas using full-waveform airborne laser scanning. Journal of Archaeological Science, vol. 35, iss. 4, pp 882-893.

Dušánek, P., 2011. Exploitation of countrywide airborne LIDAR dataset for documentation of historical human activities in countryside, Geoinformatics [online], vol.6, no.1, pp. 97102, 2011, ISSN 1802-2669, available from: http://geoinformatics.fsv.cvut.cz/pdf/geoinformatics-fce-ctu2011-06.pdf.

Faltýnová, M. \& Pavelka, K. 2011. Aerial laser scanning in archaeology, Geoinformatics [online], vol.6, no.1, pp. 103108, 2011, ISSN 1802-2669, available from: http://geoinformatics.fsv.cvut.cz/pdf/geoinformatics-fce-ctu2011-06.pdf.

Faltýnová, M., Pavelka, K., Nový, P. 2013. Mapping and visualisation of a part of medieval road - Via Magna, In: $13^{\text {th }}$ International Multidisciplinary Scientific GeoConference SGEM 2013, Bulgaria.

Gojda, M.; John, J. et al., 2013. Archeologie a letecké laserové skenování krajiny - Archaeology and airborne laser scanning of the landscape, Plzeň, pp. 87-98. ISBN 978-80-261-0194-9.

Jirásek, J; Sivek, M. Láznička, P. 2010 Ložiska nerostů. Ostrava: Anagram. ISBN 978-80-7342-206-6. http://geologie.vsb.cz/loziska/loziska/index.html.

Kuna, M. et.al. 2004. Nedestruktivní archeologie (Nondestructive archaeology), Academia, Praha. pp.255. ISBN 80200-1216-8.

Majer, J. 2004. Rudné hornictví v Čechách, na Moravě a ve Slezsku. Praha: Libri, 2004. pp. 256.

Pavelka, K.; Reznicek, J.; Koska, B. 2010. Complex documentation of the bronze equestrian statue of Jan Zizka by using photogrammetry and laser scanning. In: Proceedings of Workshop on Documentation and Conservation of Stone deterioration in Heritage Places 2010. Amman: CulTech for Archeology and Conservation, 2010, vol. 1, p. 312-328. ISBN 978-9957-485-10-8.

Sithole G. \& Vosselman G. 2004. Experimental comparison of filter algorithms for bare-earth extraction from airborne laser scanning point clouds, ISPRS Journal of Photogrammetry and Remote Sensing, vol. 59, pp 85-101, 2004.

The Czech Geological Survey http://www.geology.cz (20 June 2013).

\section{ACKNOWLEDGEMENTS}

This work was made with the financial support of the student grants of CTU in Prague (Project SGS13/055/OHK1/1T/11Practical application of modern methods of photogrammetry, remote sensing and laser scanning). Thanks to the Czech Office for Surveying, Mapping and Cadastre for lending the ALS dataset. 